\title{
Characteristics of Mesoscale Convective Complexes that Trig- gered Heavy Rainfall Related to Severe Flash Flood in Luwu, Sulawesi, Indonesia
}

\author{
Erma Yulihastin ${ }^{1, *}$, Danang Eko Nuryanto ${ }^{2}$, Trismidianto ${ }^{1}$ and Robi Muharsyah ${ }^{2}$ \\ 1 Research Center of Atmospheric Science and Technology, Research Organization of Aeronautics and Space, \\ National Agency of Research and Innovation, Bandung, West Java, 40173, Indonesia; erma.yulihas- \\ tin@lapan.go.id; midigade@gmail.com \\ 2 Research and Development Center, Indonesian Agency for Meteorology Climatology and Geophysics, Ja- \\ karta, 10720, Indonesia; danang.nur.eko@gmail.com; robi.muharsyah@gmail.com \\ * Correspondence: erma.yulihastin@lapan.go.id
}

\begin{abstract}
A severe flash flood hit Luwu, Sulawesi, Indonesia, on 13 July 2020. This flood was preceded by persistent heavy rainfall from 11 to 13 July 2020. In this study, we explore both the physical and dynamical processes that caused the heavy rainfall using a convection-permitting model with $1-\mathrm{km}$ resolution. The heavy rainfall was modulated by the development of a pair of Mesoscale Convective Complexes (MCCs) during the night. The pair of MCCs was triggered by an anti-cyclonic vorticity anomaly over the Makassar Strait and was maintained by the warm front passing between the sea and land over central Sulawesi. This front was characterized by moist-warm and cold-dry low-level air, which may have helped to extend the lifetime of the MCCs. The northwestward propagation of the MCCs was due to the interaction between predominantly southeasterly monsoon and sea surface temperature anomalies.
\end{abstract}

Keywords: mesoscale convective complex; heavy rainfall; warm front; sea surface temperature; Sulawesi

\section{Introduction}

On 13 July 2020 at around 20:00 LST, a major flash flood hit Luwu, Sulawesi, Indonesia, and killed 38 people, lost 40 people, injured 58 people, and evacuated 14.483 others [1]. The flood was triggered by persistent heavy rainfall from 11 to 13 July 2020 . This extreme event occurred during the dry season (July-August) over Indonesia which was strongly influenced by the Australian winter monsoon. However, several parts of eastern Indonesia have different annual and seasonal rainfall characteristics [2], which are strongly determined by the eastern route of the Indonesian Throughflow (ITF) and are related to warm sea surface temperatures (SSTs) [3]. The SST variability in the eastern Indonesian seas during June-July-August (JJA) is determined by the southeasterly winds, which lead to cold SSTs in the Arafura Sea and warm SSTs in the Banda Sea [4]. A recent study identified that the SST and rainfall are positively correlated over the central and eastern Indonesia seas $\left(5^{\circ} \mathrm{S}-5^{\circ} \mathrm{N}, 115-135^{\circ} \mathrm{E}\right)$ and are associated with an anticyclonic circulation at $850 \mathrm{hPa}$, which coincides with significant convergence over the regions [5].

The influence of the eastern Indonesian seas (i.e., the Maluku Sea and Arafura Sea) on rainfall intensities along the ITF pathway is determined by the warmer SSTs in the western Pacific [6]. Hence, during La Niña episodes, the warmer seas enhance the development of cumulus-congestus clouds [6] and consequently increase the frequency [7,8], amount, and intensity of extreme rainfall over eastern Indonesia (i.e., Sulawesi, Maluku, Ambon, Papua) in JJA [9]. Considering the increase in the frequency of extreme La Niña episodes under various global warming scenarios [10], the frequency of extreme events associated with extreme rainfall may be enhanced over eastern Indonesia (i.e., Sulawesi); 
however, the dynamic processes causing extreme rainfall on regional and local scales over eastern Indonesia have not been well addressed owing to the limitations of numerical studies performed at storm-resolving resolution.

The diurnal cycle of tropical convection over eastern Indonesia during JJA is controlled primarily by local seas (i.e., the Maluku Sea and Arafura Sea), which are directly connected to the warm pool in the Northwest Pacific. The diurnal rainfall over the Northwest Pacific typically reaches a maximum from the morning to the nighttime and particularly heavy rainfall is very frequent in July and August [11]. This rainfall is created by deep convective clouds reaching up to $7-8 \mathrm{~km}$ in depth. The convective activity is caused mainly by a double peak in latent heating, which is associated with both shallow precipitation and Mesoscale Convective Systems (MCSs) [12].

MCSs have been observed by radar as a deep mode $(5-6 \mathrm{~km})$ that develops from stratiform precipitation [12]. Due to the hypothesis that MCSs over the Northwest Pacific could extend as far as the eastern Indonesian seas, they may have had an influence on the extreme precipitation over Luwu, Sulawesi on 13 July 2020. This study investigates the physical and dynamical processes that caused this heavy rainfall and the associated major flash flood by using the Weather Research and Forecasting (WRF) model at 1-km spatial resolution.

\section{Materials and Methods}

We use WRF version 4.1.2 [13] with one-way nested domains, comprising a coarse domain (D01), inner domain (D02), and the innermost domain (D03), which have a spatial resolution of $9 \mathrm{~km}, 3 \mathrm{~km}$, and $1 \mathrm{~km}$, respectively (Figure 1). The center of the coarse domain is $2.702^{\circ} \mathrm{S}, 120.859^{\circ} \mathrm{E}$. The Mercator map projection is used for the model domains. The simulation configurations and physical parameterizations are summarized in Table S1. We use Betts Miller Janjić as a cumulus scheme on the first and second domain, while a no-cumulus scheme for the third domain. The parameterization schemes following Fonseca et al. [14] that best predicts the diurnal rainfall over Maritime Continent and was proven by Yulihastin et al. [15] able to capture the thunderstorm event in the term of timing, intensity, and location of precipitation. The initial and lateral boundary conditions are obtained from the global National Centers for Environmental Predictions (NCEP) Final Analysis (FNL) Operational Global Analysis data [16] and forecast grids, which have a horizontal resolution of $1.0^{\circ} \times 1.0^{\circ}$ and a temporal resolution of $6 \mathrm{~h}$. The 3-day forecasts are evaluated for each PBL scheme and the model is initialized at 00:00 UTC (07:00 LST), 11 July 2020. 


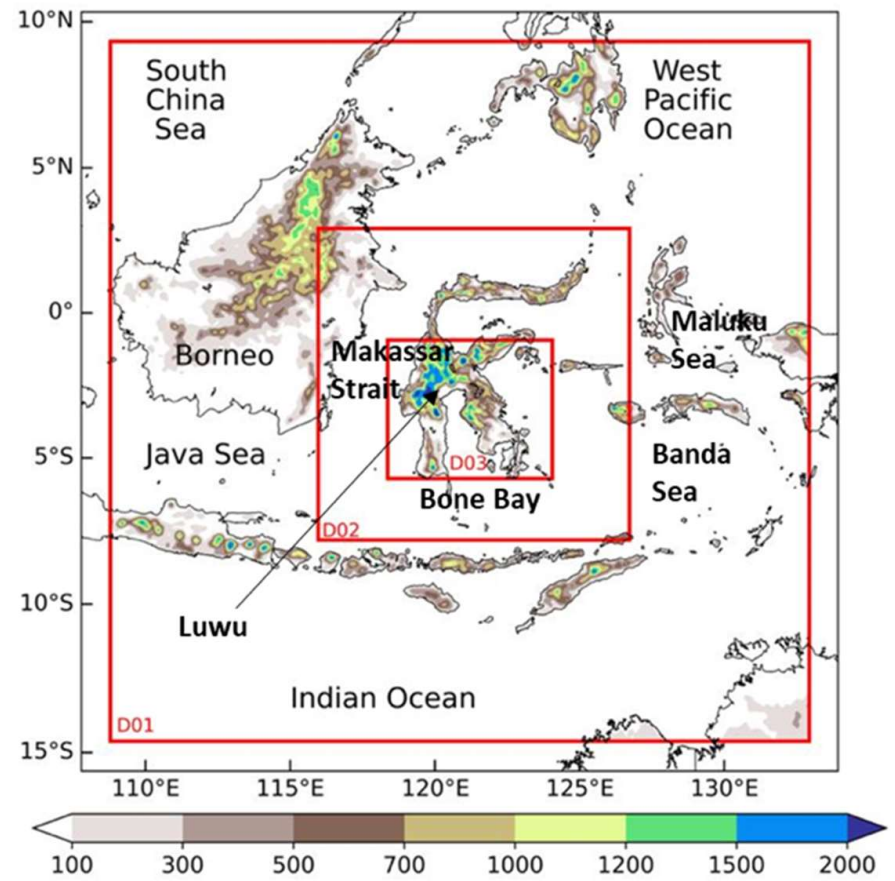

Figure 1. Simulation domain of the WRF model. Red boxes represent domains D01, D02, and D03, with resolutions of $9 \mathrm{~km}, 3 \mathrm{~km}$, and $1 \mathrm{~km}$, respectively. Color shading shows the height terrain.

We investigate the hypothesis that the SST may control the diurnal rainfall over Sulawesi Island by conducting experiments with two scenarios: (1) the default model is run without updating the SST. This is referred to as the control simulation (CTL); and (2) the model is run with the SST updated every $6 \mathrm{~h}$. This is referred to as the updated SST scenario. The CTL and SST-scenario simulations were run on all domains, with a focused study in domain 3 (D03). Both experiments were conducted with consideration of the outermost domain to capture regional circulations (e.g., the wind circulation, SST, etc.), as these influence the circulation in the innermost domain.

To confirm the heavy rainfall event, we validate the simulation results using groundbased observational data from the Agency for Meteorology Climatology and Geophysics (BMKG) station [17] and the Global Satellite Mapping of Precipitation (GSMaP) with $0.1^{\circ}$ spatial resolution [18]. Furthermore, to identify the background wind, moisture transport, specific humidity, and SST conditions, we used high-resolution near-surface ERA5 data from the European Center for Medium-Range Weather Forecasts with a spatial resolution of $0.25^{\circ} \times 0.25^{\circ}[19]$.

\section{Results and Discussion}

\subsection{Rainfall Observed and Background Conditions}

Heavy rainfall occurred from 13 to 16 July 2020 (90-120 $\left.\mathrm{mm} \mathrm{d}^{-1}\right)$ over the Luwu region, which has a relatively high terrain and is close to Bone Bay at its southern boundary with the Banda Sea (Figure 2a, b). On 13 July, stations recorded heavy rainfall over Luwu and the southern part of Sulawesi Island (Figure 2c). This heavy rainfall was triggered by the development of an anti-cyclonic vortex over the Makassar Strait near the equator (Figure 3a). This is consistent with $\mathrm{Xu}$ et al. [5], who found that a regional-scale anti-cyclonic circulation existed over central and eastern Indonesia at $850 \mathrm{hPa}$, corresponding to a significant convergence zone.

A low-level, humid, front-like synoptic pattern occurred over Bone Bay and a lowlevel, dry, front-like pattern passed over Luwu (Figure 3a). The humid southeasterly airflow was perpetuated by the predominantly easterly monsoon winds transporting moist air. Warm SSTs were observed over the Maluku Sea from 10 to 15 July 2020 (Figure 3c). 
An increase in SSTs $\left(>1^{\circ} \mathrm{C}\right)$ over the Maluku Sea was also recorded from 11 to 16 July 2020 (Figure 3d). Figure S1 shows that the warm SSTs were localized in the Maluku Sea from 11 July and reached a peak around 12-13 July 2020. Zonal differences in SST anomalies between the Banda Sea and the Arafura Sea have been identified as a response to the Australian winter monsoon [4]. However, during our study period, notable SST anomalies occurred meridionally between the Maluku Sea to the north and the Banda Sea to the south.
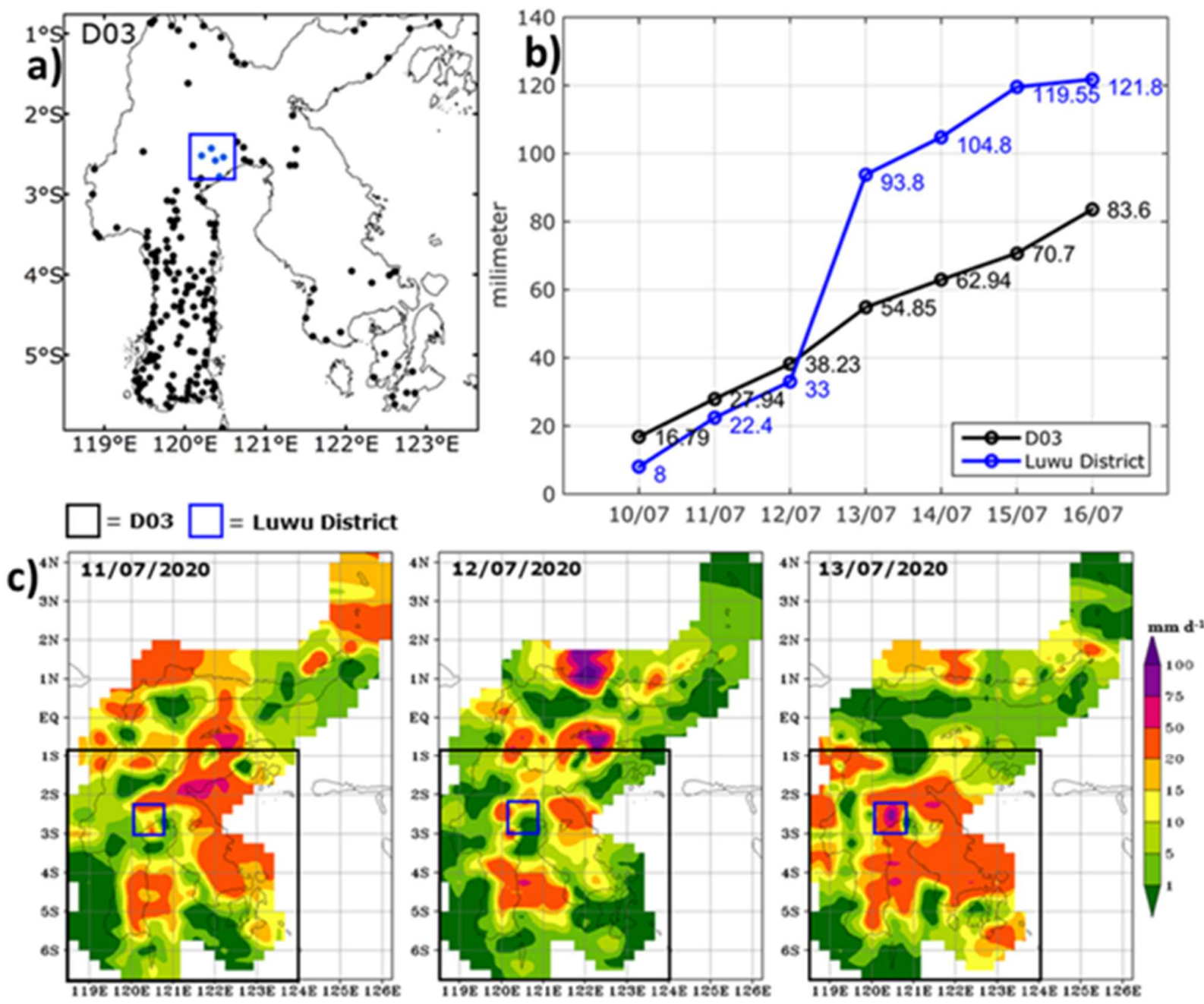

Figure 2. (a) Map of the BMKG station locations over Sulawesi Island. (b) Rainfall amount recorded by BMKG stations between Luwu and central Sulawesi (D03) from 10 to 17 July 2020. (c) Spatial map of the rainfall data from several BMKG stations.

In Figure 4, we further analyze the heavy rainfall system that led to the flash flood over Luwu on 13 July 2020 around 20:00 LST. A Mesoscale Convective Complex (MCC) is clearly seen over central Sulawesi, which split into two cells (Figure 4a) and became two large rainfall systems over central and northern Sulawesi (Figure 4b). We now consider the development of these two rainfall systems and their underlying causes. In particular, we assess whether the warm SSTs over the Maluku Sea provided the necessary water vapor to generate extensive convective activity. 

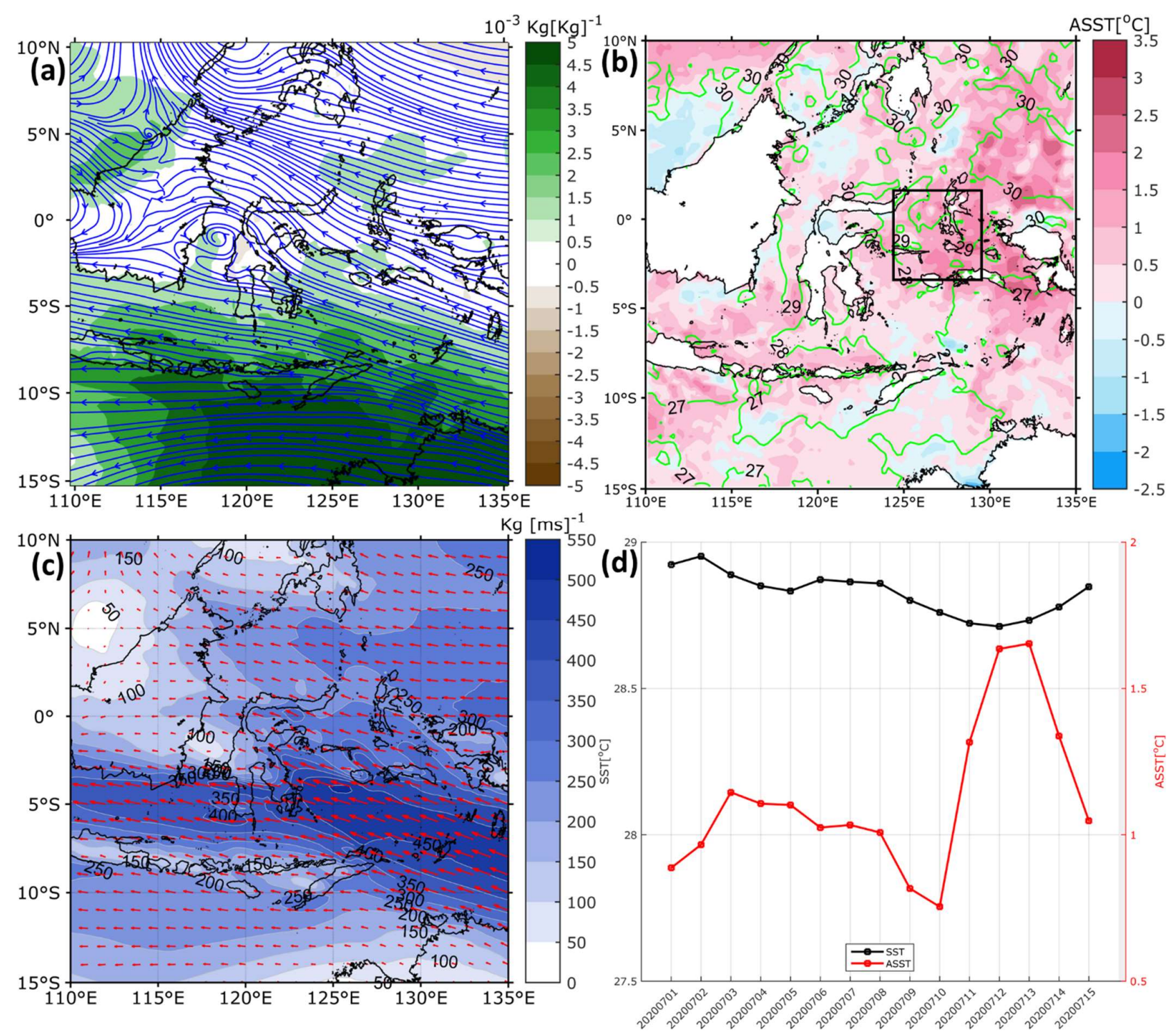

Figure 3. (a) Spatial map of specific humidity (shading) and wind at $850 \mathrm{mb}$ (streamlines) averaged from 10 to $15 \mathrm{July} 2020$ using ERA5 data. (b) Same as (a), but for SST (contours) and the SST anomaly (shading). (c) Same as (a), but for the moisture transport integrated from 1000 to $300 \mathrm{mb}$. (d) Time series of daily SST (black) and the SST anomaly (red) averaged over the area shown by the black box in panel (b) $\left(3^{\circ} \mathrm{S}-2^{\circ} \mathrm{N}, 125^{\circ} \mathrm{E}-128^{\circ} \mathrm{E}\right)$ from 10 to $15 \mathrm{July} 2020$. 

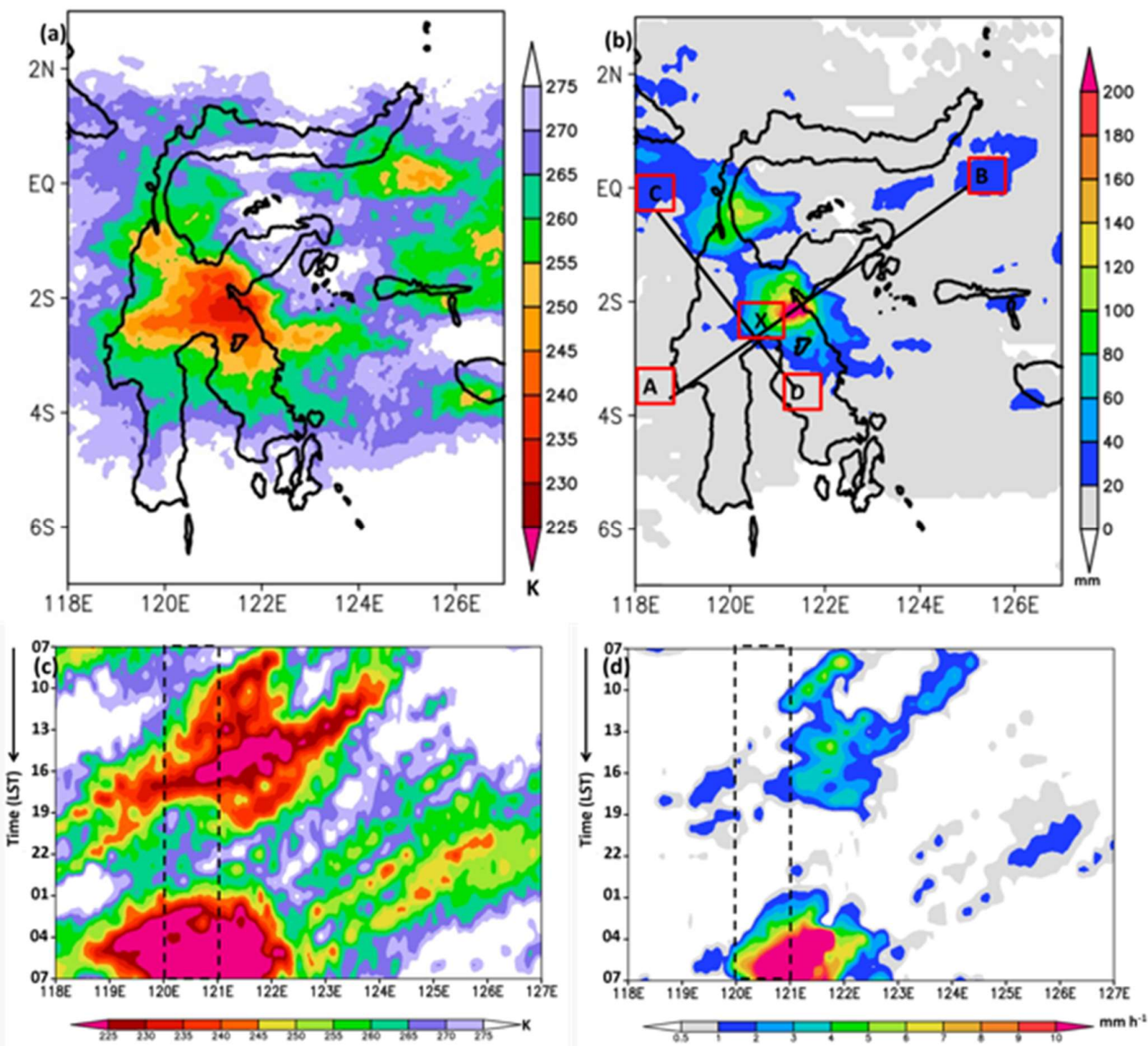

Figure 4. (a) A spatial map of daily-averaged of Black Body Temperature (TBB) cloud-top height from the Himawari satellite over 13-14 July 2020. (b) Same as (a), but for the daily accumulation of precipitation from the GSMaP satellite. The A-B and C-D transects were used in further analyses in Figures 6 and S8. The ' $X$ ' indicates the location of Luwu. (c) Timelongitude Hovmöller diagram of TBB cloud-top height averaged over $2^{\circ} \mathrm{S}-3^{\circ} \mathrm{S}$ (i.e., the Luwu region) from 13 to 14 July 2020 using Himawari satellite data. (d) Same as (c), but for diurnal precipitation using GSMaP satellite data. The black dashed box indicates the Luwu region $\left(120^{\circ} \mathrm{E}-121^{\circ} \mathrm{E}\right)$. The vertical solid line represents the east coast.

\subsection{Development of MCCs}

To investigate the role of the SST, we consider two scenarios in our numerical model: one where the SSTs are prescribed (CTL), and one where the SSTs are updated every $6 \mathrm{~h}$. We find that only one rainfall system occurs in the CTL simulation, (Figure 5a), whereas two rainfall systems occur if the SST input in the model is updated regularly (Figure $5 b$ ). Updating the SST four times a day is also useful for reducing overestimates of precipitation intensity and spatial coverage over the ocean $\left(123^{\circ} \mathrm{E}-126^{\circ} \mathrm{E}\right)$. The updated SST scenario also refines the timing of landward convective propagation, which can be seen as a peak in the precipitation intensity over the coastal region on 12 July from 17:00 LST (Figure 5c) to 13 July 13:00 LST (Figure 5d). It should also be noted that the updated 
SST scenario increases the precipitation intensity over the Luwu region in the early morning 14 July from 01:00 LST to 07:00 LST (Figure 5d), which is comparable to the satellite data observations (Figure $4 \mathrm{~d}$ ). This result is consistent with Ricchi et al. [20], who demonstrated that accurate SST model inputs improve the simulation of rainfall amount and location.

The two MCCs coincided with two rainfall systems that developed in the early morning over the eastern and northern parts of central Sulawesi, and which were oriented in a southeast-northwest direction. The evolution of the convective systems over Bone Bay and the Maluku Sea was captured in both model scenarios. However, the updated SST scenario better captured the early morning convection (Figure S2). A convective system over the ocean propagated landward at 13 July from 10:00 LST to 22:00 LST (Figure 4c) and produced precipitation of low to moderate intensity at 13 July from 16:00 LST to 20:00 LST (Figure 4d
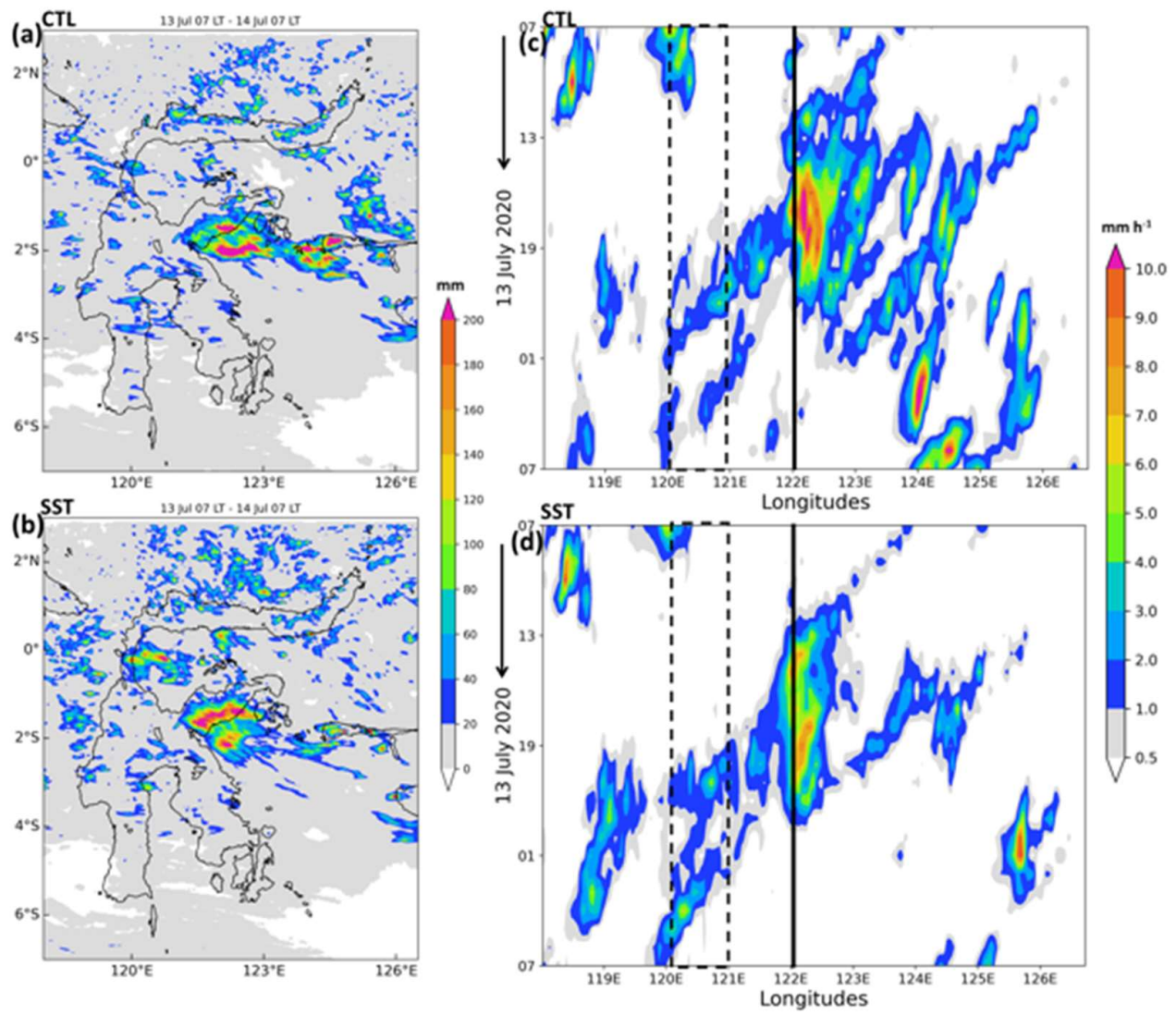

Figure 5. (a-b) Same as Figure 4b, but for simulated precipitation in the CTL and updated SST runs, respectively. (c-d) Same as Figure $4 \mathrm{~d}$, but for simulated precipitation in the CTL and updated SST runs, respectively. 

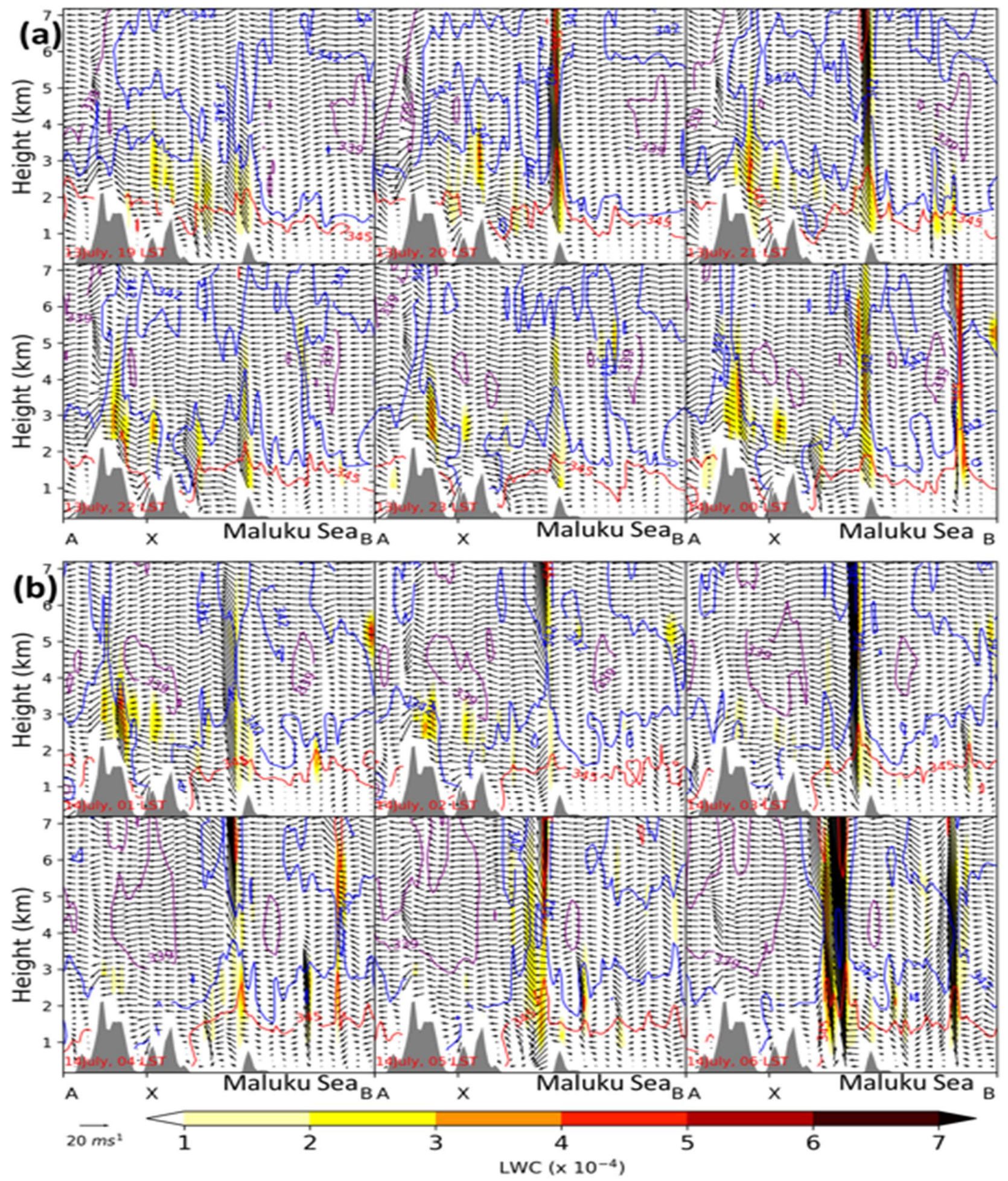

Figure 6. Height-latitude cross sections of wind (vectors; vertical component multiplied by a factor of 40), cloud mixing ratio (shading), and equivalent potential temperature anomaly (contours) on 13 July 2020 for (a) 19:00-24:00 LST and (b) 01:00-04:00 LST. The ' $X$ ' indicates the location of Luwu. For clarity, the equivalent potential temperature has had $343 \mathrm{~K}$ subtracted from it, with blue (red) lines indicating negative (positive) values. The contour interval is $1.5 \mathrm{~K}$.

The early morning convection that developed over the Luwu region originated from the coastal convection (Figure 4c) and coincided with the precipitation peak (Figure 4d). The intensification of convection in the early morning seems to be related to the 
development of the pair of MCCs inland, which started at 13 July around 23:00 LST (Figures S5-S6). The pair of MCCs became stronger between 22:00 LST and 07:00 LST over $2^{\circ} \mathrm{S}-3^{\circ} \mathrm{S}$ and $0^{\circ} \mathrm{S}-1^{\circ} \mathrm{S}$ (Figure 5a), leading to a pair of rainfall systems (Figure $5 \mathrm{~b}$ ). These features are reproduced qualitatively in the updated SST scenario (Figure 5d). Persistent precipitation occurred over the Luwu region between 07:00 LST and 19:00 LST on 13 July (Figure 5d) as a result of a long-lived MCC (Figure 5c). This possibly triggered the flash flood at 20:00 LST.

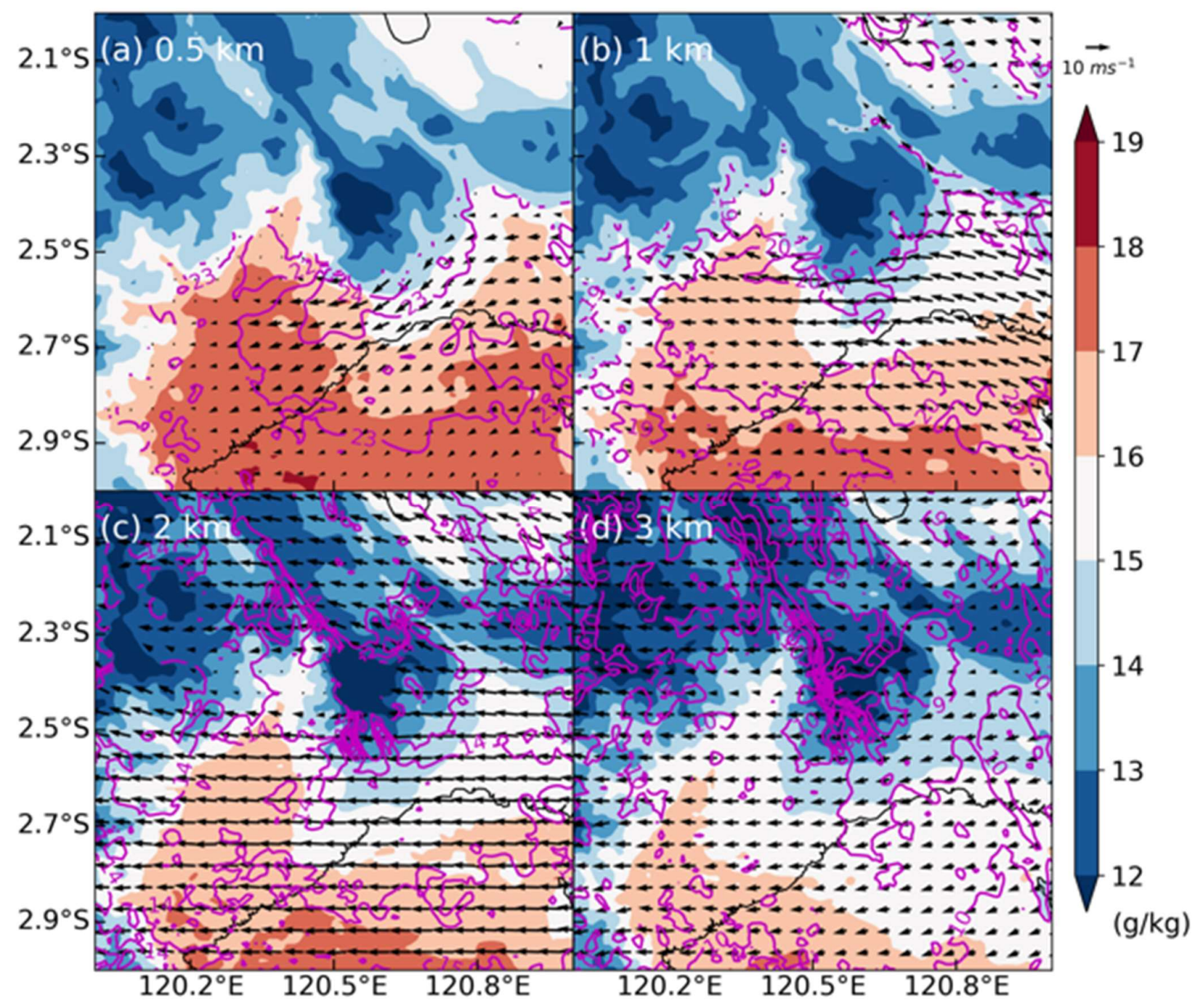

Figure 7. Horizontal distribution of temperature (contours) and water vapor mixing ratio (shading) simulated by the WRF model at 1-km resolution and averaged over 13 July 2020 (19:00-00:00 LST) at an altitude of a) 0.5 km, b) $1 \mathrm{~km}, \mathrm{c}) 2 \mathrm{~km}$, and d) $3 \mathrm{~km}$.

Because the flash flood that occurred over Luwu was associated with late afternoon rainfall, we need to verify whether the initial convection came from the Maluku Sea or Bone Bay, given the predominantly southeasterly monsoon winds. Figure 5 shows that the convective system intensified over Bone Bay and the southern coastal region of Luwu on 12 July 2020. Nonetheless, the convection still weak. A small convective system started to develop in the early morning (01:00 LST) on 13 July 2020 over the Maluku Sea near the eastern coastal region of central Sulawesi. This then extended to a wider region over Luwu and the surrounding areas in the late afternoon (19:00 LST; Figure 5). 
The intensification of convective activity over the Luwu region from the late afternoon until midnight was more strongly influenced by convection over the Maluku Sea (Figure 6) than over Bone Bay (Figure S8). The convection intensified and was maintained by a cold pool, which was initiated at 20:00 LST by near-surface (1-km altitude) cold airflow over eastern Luwu (Figure 6a). The cold pool further developed, deepened, and extended over Luwu, helping to maintain the precipitation systems over both the eastern and western parts of Luwu. The cold pool associated with the MCCs and the convection system propagating landward [21] as well as offshore [15] may also have triggered the heavy rainfall over the coastal region of Sumatra, Indonesia.

The cold pool over Luwu indirectly strengthened the convective system, which grew extensively via the back-building mechanism over the Maluku Sea on 14 July at 06:00 LST (Figure 6). The back-building was identified as a quasi-stationary southeast-northwest of double convective cells which was initiated on 13 July from 22:00 LST and became mature in the following day at 07:00 LST further dissipated until 10:00 LST (see Figures S4-S6). The back-building mechanism was previously found as a common characteristic of MCS [22-24] that can be regulated by large-scale ascent and maintained by the cold pools from the outflow $[15,24]$. However, Bone Bay also played a role in providing a warm, moist airflow near the surface, ultimately producing a warm front where the easterly airflow met with cold, dry air (Figure7). The dynamical processes leading to the heavy rainfall outlined in this study are in accordance with previous studies $[20,25]$. In particular, the warm front, cold pool, and back-building mechanism helped to generate the long-lasting rainfall system.

\section{Conclusions}

We investigated factors that might have influenced the heavy rainfall associated with a major flash flood in Luwu, Sulawesi, using experiments with the WRF model at 1-km resolution. The flash flood that occurred at around 20:00 LST was triggered by persistent moderate rainfall from morning to night over Luwu. Our results confirmed that the warm SSTs over the Maluku Sea provided abundant water vapor and intensified the convective systems over the ocean that propagated southwestward around Luwu. The interaction between northeasterly, low-level, humid airflow and elevated terrain over Luwu led to the development of a stationary cold pool at around 1-km latitude_and helped to maintain the rainfall systems over both the mainland and ocean. These findings are in accordance with previous studies demonstrating that a humid airflow near the surface may rise over a cold pool near a mountain range and reinforce heavy rainfall over coastal regions [25].

This study also found interesting features related to the development of a pair of long-lasting MCCs and a double rainfall system on 13 July from 22:00 LST to 14 July 07:00 LST over northern parts of central Sulawesi $\left(2^{\circ} \mathrm{S}-3^{\circ} \mathrm{S}\right.$ and $\left.0^{\circ} \mathrm{S}-1^{\circ} \mathrm{S}\right)$. The double rainfall system was reproduced in the model simulation with updated SSTs. The simulated rainfall confirmed that the double rainfall system developed via a back-building mechanism, which was maintained by a stationary cold pool and a warm front. This back-building mechanism help forming a long-lasting quasi-stationary convective system $(>10 \mathrm{~h})$, which found consistent with previous studies [22-24] stated that it developed along mesoscale boundaries and to be maintained by storm outflows.

On the other hand, the warm front was generated by warm and moist airflow near the surface $(0.5-3 \mathrm{~km})$ over Bone Bay in the southern part of Luwu. This was initiated due to the warm SSTs near the coastal region. The long lasting MCCs then developed as a response to both the warm front and back-building mechanism. The improved prediction of rainfall in the updated SST scenario is consistent with previous studies stating that the SST distribution plays a fundamental role in having an accurate oceanic boundary layer energy budget, which is essential for predicting rainfall [20].

In terms of the hydro-meteorological disaster over eastern Indonesia, this study suggested that numerical weather prediction of heavy rainfall events could be improved by using a high spatial resolution and by updating the SSTs as the model is running through 
data assimilation. However, it is important to note that the location of the double rainfall system in this study differed between the simulation and observations. The process for determining the precise position of the double rainfall system should be a subject of future investigation.

Supplementary Materials: The following are available online at www.mdpi.com/xxx/s1, Figure S1: Spatial maps of daily sea surface temperature, Figure S2: Spatial map of the 6-hourly evolution of surface winds and precipitation, Figure S3: Spatial maps of the 6-hourly evolution of simulated precipitation, Figure S4: Latitude-time Hovmöller diagram averaged over $120^{\circ} \mathrm{E}-121^{\circ} \mathrm{E}$ (i.e., the Luwu region) from 13 to 14 July 2020, Figure S5: Same as Figure S3, but for the 3-hourly evolution of precipitation from the GSMaP satellite, Figure S6: Same as Figure S5, but for Black Body Temperature (TBB), Figure S7: Same as Figure S5, but for the hourly evolution of TBB, Figure S8: Height-latitude cross sections of wind (vectors; vertical component multiplied by a factor of 40), cloud mixing ratio (shading), and equivalent potential temperature anomaly (contours) on 13 July 2020, Table S1: WRF model configuration for simulating precipitation over eastern Indonesia.

Author Contributions: Conceptualization, E.Y.; methodology, D.E.N.; T and R.M.; validation; formal analysis, E.Y.; writing - original draft preparation, E.Y.; writing-review and editing, E.Y.; visualization, D.E.N, T., R.M; funding acquisition, E.Y. All authors have read and agreed to the published version of the manuscript.

Funding: This research was funded by the Indonesia Educational Endowment Fund (LPDP) for funding this research through the Mandatory Productive Innovative Research program under National Research Priority [252/Menteri Ristek/Ka BRIN/E1/PRN/2020].

Data Availability Statement: The datasets of NCEP-FNL, Himawari, GSMaP, BMKG, and ERA5 are publicly available in the permanent archives: DOI: 10.5065/D6M043C6 [16], http://weather.is.kochi-u.ac.jp/ [26], ftp://rainmap:Niskur+1404@hokusai.eorc.jaxa.jp/ [18], DOI:10.1175/JCLI-D-160575.1 [17], and DOI:10.24381/cds.adbb2d47 [19], respectively.

Acknowledgments: The authors also greatly thank to BMKG for supporting station as well as radar data observations. This research supports the international program of Years of the Maritime Continent (YMC) of 2017-2021.

Conflicts of Interest: The authors declare no conflict of interest.

\section{References}

1. nasional.kompas.com. Available online: https://nasional.kompas.com/read/2020/07/20/09210791/bnpb-ungkap-tiga-penyebabbanjir-bandang-di-luwu-utara?page=all (Accessed: 27 August 2021)

2. Chang, C-P.; Wang, Z.; McBride, J.; Liu, C-H. Annual Cycle of Southeast Asia-Maritime Continent Rainfall and the Asymmetric Monsoon Transition. Journal of Climate 2005, 18 287-301

3. Aldrian, E.; Susanto, R.D. Identification of three dominant rainfall regions within Indonesia and their relationship to sea surface temperature. Int. J. Climatol 2003, 23, 1435-1452

4. Kida, S.; Richards, K.J. Seasonal Sea surface temperature variability in the Indonesian Seas. 2009, J. Geophys. Res. 114 C06016

5. Xu, Q.; Guan, Z.; Jin, D.; Hu, D. Regional Characteristics of Interannual Variability of Summer Rainfall in the Maritime Continent and Their Related Anomalous Circulation Patterns. Journal of Climate 2019, 32, 4179-4192

6. Lee, H. General Rainfall Patterns in Indonesia and the Potential Impacts of Local Seas on Rainfall Intensity. Water 2015, 7, 17511768

7. Villafuerte, M.Q.; Matsumoto, J. Significant Influences of Global Mean Temperature and ENSO on Extreme Rainfall in Southeast Asia. Journal of Climate 2015, 28, 1905-19

8. Lestari, S.; Hamada, J-I.; Syamsudin, F.; Sunaryo; Matsumoto, J.; Yamanaka, M.D. ENSO Influences on Rainfall Extremes around Sulawesi and Maluku Islands in the Eastern Indonesian Maritime Continent. SOLA 2016, 12, 37-41

9. Supari; Tangang, F.; Salimun, E.; Aldrian, E.; Sopaheluwakan, A.; Juneng, L. ENSO modulation of seasonal rainfall and extremes in Indonesia. Clim Dyn 2016, 51, 2559-2580

10. Cai. W.; Wang, G.; Santoso, A.; McPhaden, M.J.; Wu, L.; Jin, F-F.; Timmermann, A.; Collins, M.; Vecchi, G.; Lengaigne, M.; et al. Increased frequency of extreme La Niña events under greenhouse warming. Nature Clim Change 2015, 5, 132-137

11. Takahashi, H.G. Seasonal and Diurnal Variations in Rainfall Characteristics over the Tropical Asian Monsoon Region Using TRMM-PR Data. SOLA 2016, 12A, 22-27

12. Liu, C.; Shige, S.; Takayabu, Y.N.; Zipser, E.; Latent Heating Contribution from Precipitation Systems with Different Sizes, Depths, and Intensities in the Tropics. Journal of Climate 2015, 28, 186-203 
13. Skamarock, W.C.; Klemp, J.B.; Dudhia, J.; Gill, D.O.; Barker, D.M.; Duda, M.G.; Huang X-Y.; Wang, W.; Powers, J.G. A Description of the Advanced Research WRF Version 3 Mesoscale and Microscale Meteorology Division, National Center for Atmospheric Research Boulder, Colorado, USA, 2008; 126

14. Fonseca, R.M.; Zhang, T.; Yong, K-T. Improved simulation of precipitation in the tropics using a modified BMJ scheme in the WRF model Geosci. Model Dev. 2015, 8, 2915-2928

15. Yulihastin, E.; Trismidianto; Nuryanto, D.E. Convective Cold Pool Associated with Offshore Propagation of Convection System over the East Coast of Southern Sumatra Advances in Meteorology 2021 (Accepted)

16. Kalnay, E.; Kanamitsu, M.; Kistler, R.; Collins, W. The NCEP/NCAR 40-Year Reanalysis Project. Bulletin of the American Meteorological Society 1996, 77, 437-472

17. Besselaar, E.J.M.; Schrier, G.; Cornes, R.C.; Iqbal, A.S.; Klein, T.A.M.G. SA-OBS: A Daily Gridded Surface Temperature and Precipitation Dataset for Southeast Asia. J. Climate 2017, 30, 5151-5165

18. Kubota, T.; Shige, S.; Hashizume, H.; Aonashi, K.; Takahashi, N.; Seto, S.; Hirose, M.; Takayabu, Y.N.; Ushio, T.; et al. Global Precipitation Map Using Satellite-Borne Microwave Radiometers by the GSMaP Project: Production and Validation. IEEE Trans. Geosci. Remote Sensing 2007, 45, 2259-2275

19. Hersbach, H.; Bell, B.; Berrisford, P.; Hirahara, S.; Horányi, A.; Muñoz-Sabater, J.; Nicolas, J.; Peubey, C.; Radu, R.; Schepers, D.; et al. The ERA5 global reanalysis Q.J.R. Meteorol. Soc. 2020, 146, 1999-2049

20. Ricchi, A.; Bonaldo, D.; Cioni, G.; Carniel, S.; Miglietta, M.M. Simulation of a flash-flood event over the Adriatic Sea with a highresolution atmosphere-ocean-wave coupled system. Sci Rep 2021, 11, 9388

21. Trismidianto; Hadi, T.W.; Ishida, S.; Moteki, Q.; Manda, A.; Iizuka, S. Development Processes of Oceanic Convective Systems Inducing the Heavy Rainfall over the Western Coast of Sumatra on 28 October 2007 SOLA 2016, 12, 6-11

22. Schumacher, R.S.; Johnson, R.H. Organization and Environmental Properties of Extreme-Rain-Producing Mesoscale Convective Systems. Mon. Weather. Rev. 2005, 133, 16

23. Xiaofang, W.; Chunguang, C.; Wenjun, C.; Yan, S. Modes of Mesoscale Convective System Organization During Meiyu Season over the Yangtze River Basin. J. Meteor. Res. 2014, 28, 111-126

24. Schumacher, R.S.; Rasmussen, K.L. The formation, character and changing nature of mesoscale convective systems. Nature Review 2020, 1, 300-314

25. Seko, H.; Hayashi, S.; Kunii, M.; Saito, K. Structure of the Regional Heavy Rainfall System that Occurred in Mumbai, India, on 26 July 2005 SOLA 2008, 4, 129-132

26. Bessho, K.; Date, K.; Hayashi, M.; Ikeda, A.; Imai, T.; Inoue, H.; Kumagai, Y.; Miyakawa, T.; Murata, H.; Ohno, T.; et al. An Introduction to Himawari-8/9-Japan's New-Generation Geostationary Meteorological Satellites. Journal of the Meteorological Society of Japan 2016, 94, 151-183 